\title{
ARTYKULY
}

Jacek Soszyński

Warszawa

\section{Dzieje starożytne w Fasciculus temporum Wernera Rolevincka}

Gatunek kronik uniwersalnych powstał u schyłku starożytności i był chrześcijańską odpowiedzią na potrzebę włączenia dziejów wyznawców prężnego, niedawno zalegalizowanego wyznania w uznaną historię cywilizacji grecko-rzymskiej. Jakkolwiek chrześcijanie odziedziczyli po „starszych braciach w wierze" kompletny zarys swych dziejów w postaci ksiag historycznych Biblii, to jednak szeroko znana i akceptowana w wykształconych kręgach cesarstwa rzymskiego historia zupełnie milczała na temat wypadków opisanych w Piśmie świętym. Powodowało to zrozumiałe niezadowolenie wśród intelektualistów chrześcijańskich, którzy dokładali wszelkich starań, by dzieje ich religii weszły do obowiązującego kanonu wiedzy historycznej. W takiej również perspektywie należy rozpatrywać powstanie kroniki uniwersalnej Euzebiusza z Cezarei, przethumaczonej przez Hieronima na język łaciński ${ }^{1}$.

Kroniki uniwersalne weszły więc w obieg intelektualny przede wszystkim jako dzieła uczone i skierowane do intelektualistów, tym bardziej, że pierwsze wieki funkcjonowania tego typu tekstów zbiegły się z poważ-

\footnotetext{
${ }^{1} \mathrm{Na}$ temat charakterystyki kronik uniwersalnych i genezy tego gatunku zob.: Marcin Polak, Kronika papieży i cesarzy, tekst łaciński wg wyd. Ludwiga Weilanda (MGH Scriptores, t. XII), przekład polski i komentarz: Agnieszka Fabiańska i Jacek Soszyński, Wstęp: J. Soszyński, Kęty 2008, s. 22-27, gdzie zestawiona jest także literatura. Z nowszych publikacji ważne są: Graeme Dunphy, World chronicles, [w:] Encyclopedia of the Medieval Chronicle, red. G. Dunphy, Leiden - Boston 2010, t. 2: J-Z, kol. 1528-1532 oraz Andrea Worm, Diagrammatic chronicles, tamże, t. 1: A - I, kol. 521-532. Istotne są także hasła zamieszczeone w tejże encyklopedii, poświęcone indywidualnym kronikom uniwersalnym.
} 
nymi, a nierzadko burzliwymi, dyskusjami na temat samego kalendarza i poprawnego ustalenia chronologii wydarzeń. Jednak tym, co w sposób zasadniczy odróżniało kroniki uniwersalne od wcześniejszych greckich i rzymskich historii powszechnych, był podtekst historiozoficzny - sposób postrzegania dziejów jako całości. Novum wprowadzone przez chrześcijan polegało na przyjęciu linearnej koncepcji dziejów, rozpoczynających się w momencie określonym przez sześć dni Stworzenia, i zmierzających do spełnienia w dniu Sądu Ostatecznego. Nauka ta nosi nazwę historii świętej ${ }^{2}$. Ta obca filozofii greckiej koncepcja chrześcijańska legła u podstaw wszystkich kronik uniwersalnych i stanowi jeden z wyznaczników tego gatunku. W wieku XVIII, gdy w wyniku rozwoju myśli oświeceniowej, koncepcja ta zeszła na dalszy plan, gatunek kronik uniwersalnych się wyczerpał i został zastapiony przez nowożytną historiografię powszechną.

Wracając jeszcze na chwilę do początków gatunku warto zauważyć, że kronika Euzebiusza-Hieronima (jak należy nazwać Hieronimowy uzupełniony przekład Chronici canones Euzebiusza z Cezarei) to skomplikowana i monstrualnie dhuga tablica synchronistyczna, całkowicie pozbawiona narracji ${ }^{3}$. Uczyć się z niej historii, bez pomocy nauczyciela lub podręcznej biblioteki, było bardzo trudno. Znakomicie się natomiast sprawdzała jako encyklopedia dziejów w rękach osoby już gruntownie wykształconej i pracującej intelektualnie. Tradycja wykładu dziejów w formie tablicy chronologiczno-synchronistycznej, zapoczątkowana przez Euzebiusza z Cezarei w historiografii łacińskiej, znalazła licznych kontynuatorów przez całe średniowiecze, a nawet w czasach nowożytnych ${ }^{4}$. W tym nurcie mieści się najpopularniejsze kompendium historii powszechnej rozwiniętego średniowiecza - Kronika papieży i cesarzy Marcina Polaka. Powstawały również inne odmiany kronik uniwersal-

${ }^{2}$ Por. Kazimierz Dola, Po co pisano historię Kościoła? [w:] Causa creandi, pod red. Stanisława Rosika i Przemysława Wiszewskiego, Wrocław 2005, s. 23-31. W wypadku historii rozumianej jako boski plan zbawienia, pamiętać także należy, że jej zakres nie pokrywa się z tym, co pod pojęciem „historii” rozumiano wcześniej i później. W myśl tej doktryny historia ogarniała całość bytności człowieka na ziemi, od Stworzenia po Sąd Ostateczny, tym samym obejmując również czas, który będzie dany od teraźniejszości do paruzji.

${ }^{3}$ Genezę, strukturę i koncepcję historii Euzebiusza z Cezarei omawia Anna Kotłowska, Obraz dziejów w Chronici Canones Euzebiusza z Cezarei, Poznań 2009, gdzie zamieszczona jest również wyczerpująca bibliografia.

${ }^{4}$ Problem zastosowania układu graficznego kronik uniwersalnych poruszyła A. Worm, Layout, [w:] Encyclopedia of the Medieval Chronicle, t. 2: J-Z, kol. 1001-1011 (gdzie wyczerpująca bibliografia), w piśmiennictwie zaś polskim J. Soszyński, Od synchronizacji do wizualizacji. Prezentacja dziejów na kartach średniowiecznych kronik uniwersalnych, „Z Badań nad Książką i Księgozbiorami Historycznymi”, 5:2011, s. 169-184. 
nych, które nie rezygnowały z potoczystej narracji i wzbogacały je informacjami z innych dziedzin wiedzy lub, tak jak uznawana przez niektórych za najwyższy wzlot gatunku - Chronica sive historia de duabus civitatibus Ottona z Freising - przegląd dziejów świata traktowały jako kanwę do wyłożenia własnych pomysłów historiozoficznych.

Kroniki uniwersalne długo cieszyły się niesłabnącą popularnością. Przez całe średniowiecze odnotowujemy ich stałą obecność, a nawet, z zachowaniem pewnej dozy dystansu do tego stwierdzenia, można mówić o stopniowym narastaniu ich powodzenia wśród autorów i czytelników. Na pierwszy rzut oka popularność ta wynikała z faktu, że przedstawiały całokształt historii ludzkości jako logiczny proces, czyniąc je zrozumiałymi na gruncie objawienia religijnego. Tymczasem przegląd wstępów i treści przeważającej części przedstawicielek tego gatunku prowadzi do podobnych wniosków, co w przypadku pierwowzoru - kroniki Euzebiusza-Hieronima - i wskazuje na fakt, że autorom przyświecały inne cele niż przekazanie koncepcji historii świętej. Przede wszystkim, kroniki te były pomyślane jako pomoce encyklopedyczne, przeznaczone dla środowisk przygotowanych intelektualnie do ich odbioru. W intencji autorów najczęściej były kierowane do osób, które odpowiadały za magisterium Kościoła, a więc tych, których zadaniem było nauczanie wiernych. Powodowało to, że autorzy chętnie pomijali treści, uważane przez nich za oczywiste, w tym wykład teoretyczny historii świętej. W ten sposób stajemy w obliczu swoistego paradoksu: kroniki uniwersalne są wykładem historii świętej, chociaż nie zawierają jej objaśnienia. $Z$ tradycją tą wyraźnie zrywa ostatnia wielka kronika uniwersalna średniowiecza - Fasciculus temporum Wernera Rolevincka; wielka oczywiście nie w znaczeniu objętości, ale z uwagi na jej niespotykane wcześniej rozpowszechnienie.

Werner Rolevinck, autor Fasciculus temporum, pochodził z Westfalii ${ }^{5}$. Jego biografia nie obfituje $\mathrm{w}$ dramatyczne wydarzenia. Urodził się

${ }^{5} \mathrm{Na}$ temat W. Rolevincka i jego twórczości zob.: A. Worm, Rolevinck, Werner, [w:] Encyclopedia of the Medieval Chronicle, t. 2: J-Z, kol. 1292-1294; Volker Honemann, Theologen, Philospohen, Geschichtsschreiber, Dichter und Gelehrte im 'Fasciculus Temporum' des Werner Rolevinck. Ein Beitrag zur spätmittelalterlichen Literaturgeschichtsschreibung, [w:] Der weite Blick des Historikers. Einsichten in Natur-, Landes- und Stadtgeschichte. Peter Johanek zum 65. Geburtstag, hg. von Wilfried Ehbrecht, Angelika Lampen, Franz-Joseph Post und Mechthild Siekmann, Köln - Weimar - Wien 2002, s. 337-356; Laviece Cox Ward, Seville's First Illustrated Book: The 1480 Edition of the Fasciculus Temporum and its Spanish Printers, Bartholomeo Segura and Alfonso de Puerto, [w:] Los Cartujos en Andalucia, ed. James Hogg, A. Girard, t. 2, Salzburg 1999 (Analecta Cartusiana, 150), s. 219-244; F. A. Janssen, Ther Hoernen and Rolevinck: A new angle on an Interesting Collaboration, „Quaerendo”, 27:1997, s. 300-306; E.A. Overgaauw, Observations on the Manuscripts of Werner Rolevincks Fasciculus Temporum: The Dating of the Fasciculus Manuscript in Arnhem Public Library, „Quaerendo”, 22:1992, s. 292-300; 
w 1425 roku jako syn chłopa z okolic Laer. Jego ojciec był na tyle zamożny, że mógł zadbać o pogłębione wykształcenie Wernera. Po odebraniu wstępnej edukacji, co do miejsca i zakresu której możemy jedynie snuć domysły, w roku akademickim 1443/44 Rolevinck zapisał się na wydział prawa Uniwersytetu w Kolonii. Jednak w 1447 r. ostatecznie zrezygnował z perspektyw kariery, czy to duchownej czy świeckiej, które otwierały przed nim studia prawnicze i wstapił do zakonu kartuzów. Został członkiem kolońskiej kartuzji pod wezwaniem św. Barbary, gdzie pozostawał do śmierci podczas zarazy w 1502 r. Już jako kartuz, dzięki swym licznym pismom z zakresu teologii, kaznodziejstwa i historiografii, zdobył znaczny rozgłos. Johannes Trithemius, benedyktyński opat i uczony, autor bibliograficznego słownika pisarzy niemieckich, pozostawał z nim w korespondencji, a nawet osobiście odwiedził go w Kolonii. W poświęconym Rolevinckowi biogramie wymienia tytuły 33 prac powstałych do połowy $1495 \mathrm{roku}^{6}$. Lista ta $\mathrm{z}$ pewnością nie wyczerpuje twórczości kolońskiego kartuza - chociażby dlatego, że sporządzona została na siedem lat przed jego śmiercią - ale daje nam wgląd w zakres jego zainteresowań, które sięgały od zagadnień egzegetycznych i duszpasterskich (kaznodziejstwo, katecheza), przez prawnicze i społeczne, po historyczne, tak w wymiarze ogólnodziejowym jak i lokalnym, czego znakomitym wyrazem jest księga De laude antiquae Saxoniae nunc Westfaliae dictae ${ }^{7}$. Mimo to, Werner Rolevinck nie doczekał się jak dotychczas wyczerpującej, wszechstronnej biografii. Przyczyny tego doszukiwać się najpewniej należy w fakcie, że większość jego pism do dziś dzień pozostaje bez wydań krytycznych. Nawet najlepiej rozpoznane przez historyków jego dzieło, Fasciculus temporum, nie jest pod tym względem wyjątkiem.

Lotte Hellinga, Margaret Lane Ford, Deletion or Addition: A Controversial Variant in Werner Rolewinck's „,Fasciculus Temporum” (Cologne, 1474), „Library Chronicle”, 21:1991, 3/4, s. 61-79; F. A. Janssen, Author and Printer in the History of Typographical Design, „Quaerendo”, 21:1991, s. 11-37; Volker Henn, ,,... quod inter dominos et subiectos esse debet mutua dilectio." Zu den Ständetraktaten des Kölner Kartäusers Werner Rolevinck, [w:] Die Kölner Kartause um 1500, hg. Werner Schäfke, Köln 1991, s. 199-211; Volker Henn, Der Bauernspiegel des Werner Rolevinck: „, De regimine rusticorum” und die soziale Lage der westfälischen Bauern im späten Mittelalter, „Westfälische Zeitschrift”, 128:1978, s. 289-313; Hermann Bücker, Werner Rolevinck (1425-1502). Leben und Persönlichkeit im Spiegel des Westfalenbuches, Münster 1953; Franz Xaver von Wegele, Rolevinck Werner, [w:] Allgemeine Deutsche Biographie, t. 29, Leipzig 1889, s. 72-73.

${ }^{6}$ Cathalogus illustrium virorum Germaniam suis ingenijs et lucubrationibus omnifariam exornantium: domini Iohannis Tritemij abbatis Spanhemensis..., [Mainz: Peter von Friedberg] 1495, ISTC it00433000, GW M47516; k. 59v-60r - http://diglib.hab.de/ inkunabeln/115-4-quod-4/start.htm 12 grudnia 2012].

${ }^{7}$ W. Rolevinck, Ein Buch zum Lobe Westfalens, des alten Sachsenlandes. Der Text der lateinischen Erstausgabe vom Jahre 1474 mit deutscher Übersetzung, hrsg. von Hermann Bücker, Aschendorff - Münster 1982. 
Fasciculus temporum okazał się bardzo popularny. Kroniki uniwersalne w ogóle często potrafiły osiagać niezwykłe upowszechnienie. W powyższym kontekście przywołajmy dwa dużo mówiące przykłady: Etymologie Izydora z Sewilli, które zawierają krótką kroniczkę uniwersalna, i trzynastowieczną Kronike papieży i cesarzy Marcina Polaka. Co do pierwszej wiemy, że przez nieco więcej niż dwa pierwsze wieki funkcjonowania tego tekstu z Sewilli wywieziono na wschód za Pireneje 54 kompletne egzemplarze (i wiele więcej fragmentów), co na okres od połowy VII do połowy IX w. było liczbą zaiste imponująca ${ }^{8}$. W odniesieniu do drugiego przykładu, systematyczna kwerenda w bibliotekach na całym świecie ustaliła, że do dziś zachowało się przeszło czterysta średniowiecznych jej odpisów ${ }^{9}$. Porównanie tych dwóch kwerend jest uprawnione, albowiem w obu wypadkach mamy do czynienia z losowym zachowaniem informacji o produkcji książki w dobie transmisji rękopiśmiennej oraz z podobną rozpiętością czasu, w którym powstawały odpisy. Uwzględniając wszelkie różnice, które muszą dzielić wczesne średniowiecze i jego ostatnie dwa stulecia, takie jak rozwój ekonomiczny, techniczny, edukacyjny itd., lub zdecydowanie mniejsze prawdopodobieństwo zachowania się informacji o istnieniu rękopisu we wczesnym średniowieczu, trzeba przyznać, że niemal dziesięciokrotna przewaga ilościowa odpisów kroniki Marcina Polaka bynajmniej nie uprawnia do mówienia o cywilizacyjnym przełomie. Bardzo popularna kronika uniwersalna w dobie transmisji rękopiśmiennej zapewne osiagała rozpowszechnienie, które można liczyć w setkach odpisów; w wyjattkowych przypadkach liczba odpisów przekraczała tysiąc, a może nawet dwa tysiące egzemplarzy. Dopiero przypadek Fasciculus temporum wprowadza nas w zupełnie inne przedziały ilościowe, ponieważ jego upowszechnienie nastapiło za pomocą druku.

${ }^{8}$ B. Bischoff, Die europäische Verbreitung der Werke Isidors von Sevilla, [w:] tenże, Mittelalterliche Studien. Ausgewählte Aufsätze zur Schriftkunde und Literaturgeschichte, Bd I, Stuttgart 1966, s. 171-194; Charles H. Haskins, The Renaissance of the Twelfth Century, New York 1957, s. 81.

${ }^{9}$ A.-D. von den Brincken, Studien zur Überlieferung der Chronik Martins von Troppau, Teil 1, „Deutsches Archiv für Erforschung des Mittelalters”, 41:1985, s. 460-531, Teil 2, „Deutsches Archiv für Erforschung des Mittelalters”, 45:1989, s. 551-591; Studien zur.. Erste Nachträge, „Deutsches Archiv für Erforschung des Mittelalters”, 50:1994, s. 611-613; W.-V. Ikas, Neue Handschriftenfunde zum Chronicon pontificum et imperatorum des Martin von Troppau, ,Deutsches Archiv für Erforschung des Mittelalters", 58:2002, s. 521-537. Chociaż zestawienia te, przynajmniej w stosunku do rękopisów polskich, traktują tzw. kroniki martyniańskie (przeróbki i naśladownictwa właściwej kroniki Marcina) na równi z Kronika papieży i cesarzy, liczbę przeszło czterystu zachowanych kopii można traktować poważnie, ponieważ nadal są, i zapewne jeszcze dhugo będa, odkrywane kolejne odpisy. 
Wczesna historia wydań drukowanych Fasciculus temporum jest pod tym względem wielce pouczająca. Spisana w latach 1468-1472 kronika najpóźniej w 1474 r. trafiła pod prasy drukarskie. Na ogół w literaturze przedmiotu przyjmuje się, że pierwsze jej wydanie ukazało się w Kolonii w oficynie Arnolda Thera Hoernena ${ }^{10}$. Autorzy Incunabula Poloniae wymieniająjednak na pierwszym miejscu inne wydanie kolońskie, wydrukowane przez Nicolausa Götza, które datują „nie wcześniej niż w 1474 r." ", a repertoria Deckerta i Goffa postulują nawet datację po październiku $1473^{12}$. Podobnie na 1473 r. wydanie Götza datuje baza Gesamtkatalog der Wiegendrucke ${ }^{13}$. Amerykańska historyk Laviece Cox Ward wszelako wskazuje w tym kontekście na dwa dowody źródłowe przesądzające o tym, że Rolevinck współpracował z Hoernenem osobiście, co w domyśle ma ugruntowywać status tego wydania jako pierwodruku przygotowanego pod nadzorem samego autora. Pierwsze $\mathrm{z}$ owych świadectw to kolofon rzeczonej książki: „Impressa est hec cronica, que dicitur Fasciculus temporum, Colonie Agrippine, sicut ab autore suo quodam deuoto carthusiensi Colonie edita est, ac secundum primum exemplar, quod ipse venerabilis autor propriis conscripsit manibus, ad finem usque deducta per me Arnoldum Ther Huerenem, sub annis Domini M CCCC LXXIIII. De quo sit Deus benedictus in secula. Amen". Drugi pochodzi z wydanego przez Hoernena dwa lata wcześniej Sermo de Presentatione Beatae Mariae Virginis (Kolonia 1472) autorstwa Wernera Rolevincka: „Et quia nulla alia via cicius et facilius potuit plurimis personis communicari. procuraui solicite. eundem per artem impressoriam librorum ad. magnam numerositatem multiplicari in ciuitate coloniensi. per discretum virum arnoldum ther hoernen qui habitat infra sedecim domus prope conuentum fratrum praedicatorum. Apud quem huiusmodi sermo inuenietur sub debita correctione et nihilominus pro levi precio"14. Przytoczone powyżej

${ }^{10}$ ISTC ir00254000; GW M38693; IBP 4782.

${ }^{11}$ ISTC ir00253000; GW M38682; IBP 4781.

12 Deckert Helmut, Katalog der Inkunabeln der sächsischen Landesbibliothek zu Dresden, ein Bestandsverzeichnis nach den Kriegsverlusten des Jahres 1945, Leipzig 1957, $\mathrm{nr}$ 551; Frederick R. Goff, Incunabula in American Libraries: A Third Census of Fifteenthcentury Books Recorded in North American Collections, New York 1964, nr R-253.

${ }^{13}$ Por. wyżej przyp. 11.

${ }^{14}$ Cyt. za L. C. Ward, A Carthusian View of the Holy Roman Empire: Werner Rolevinck's 'Fasciculus Temporum', [w:] Die Kartäuser und das Römische Reich, z. 4, Salzburg 1999 (Analecta Carthusiana, 140), s. 25, przyp. 4 (zachowana grafia autorki). Nie udało mi się dotrzeć do tego inkunabułu. Autorka nie podaje żadnych odsyłaczy do katalogów, GW zaś nie odnotowuje takiego wydania. Baza ta wylicza natomiast cztery wydania kolońskie wytłoczone przez wspomnianego drukarza: 1470 (GW M38815, M38816) oraz ok. 1471 (GW M38810) i ok. 1471 (GW M38811). Za wyjątkiem GW M38816 wszystkie są dostępne przez internet. żaden z nich jednak nie zawiera powyższego zdania. 
cytaty faktycznie dowodza, że Rolevinck współpracował z Hoernenem przy druku własnych pism. W żaden jednak sposób nie przesądzają kwestii, że wydanie Hoernena ukazało się wcześniej niż edycja Götza. Ewidentnie problem ten wymaga dalszych badań źródłowych.

Jednakże nie sposób zaprzeczyć, że samo istnienie problemów z ostatecznym ustaleniem, które wydanie Rolevinckowej kroniki ukazało się pierwsze, wskazuje na fakt, iż Fasciculus temporum szybko stał się bardzo popularny. W 1476 r., zaledwie dwa lata po pojawieniu się pierwodruku (bez względu na to, czy wyszedł on z pod pras Hoernena czy Götza), w tej samej Kolonii, w oficynie Conrada Wintersa ukazało się kolejne wydanie ${ }^{15}$, a w 1477 r. w Spirze edycja Petrusa Dracha ${ }^{16}$. Niedługo potem wyszły dalsze wydania Fasciculus temporum: w Kolonii jedno w oficynie Nicolausa Götza $^{17}$ i trzy w drukarni Henricusa Quentella $\left(1479^{18}, 1480^{19}\right.$ i $1481^{20}$ ). Tymczasem od 1479 r. zaczynają się ukazywać edycje tekstu dokonane przez drukarzy weneckich: Georgiusa Walcha ${ }^{21}$, Erharda Ratdolta $\left(1480^{22}\right.$ i $1481^{23}$ ). W 1480 r. kronika Rolevincka przekroczyła Pireneje i ukazała się w Sewilli nakładem oficyny Alfonso del Puerto i Bartolomé Segury ${ }^{24}$. Wydanie to było wzorowane na weneckiej edycji Georgiusa Walcha. Do końca 1483 roku odnotowujemy jeszcze trzy dalsze wydania $\mathrm{z}$ terenów Niemiec $^{25}$. Tak więc, w dziesięć lat od ukazania się pierwodruku, świat ujrzało razem licząc piętnaście edycji Fasciculus temporum.

Rolevinckowe dzieło cieszyło się wyjątkowym powodzeniem nie tylko w pierwszej dekadzie po zaistnieniu na rynku księgarskim, choć niewątpliwie był to jego okres szczytowy. Do śmierci autora w 1502 r. ukazało się razem przeszło trzydzieści wydań Fasciculus temporum, a na dodatek dokonano jego przekładów na języki: niemiecki, średnioniderlandzki i francuski, które również trafiły do druku (niektóre nawet wielokrotnie).

\footnotetext{
${ }^{15}$ ISTC ir00255000; GW M38695; IBP 4783.

${ }^{16}$ ISTC ir00257000; GW M38715; IBP 4784.

${ }^{17}$ ISTC ir00258000; GW M38648; IBP 4785. Druk ten również przysparza kłopotów z datacja, ponieważ w różnych repertoriach datowany jest na rok albo 1478 albo 1479.

${ }^{18}$ ISTC ir00259000; GW M38685; IBP 4786.

${ }^{19}$ ISTC ir00262000; GW M38687; IBP 4788.

${ }^{20}$ ISTC ir00265000; GW M38688; IBP 4790.

${ }^{21}$ ISTC ir00260000; GW M38741; IBP 4787.

${ }^{22}$ ISTC ir00261000; GW M38729; IBP 4789.

${ }^{23}$ ISTC ir00264000; GW M38732; IBP 4792.

${ }^{24}$ ISTC ir00263000; GW M38711. Wydanie te szczegółowo omawia L. C. Ward, The Fasciculus Temporum and Early Printing in Spain..., s. 347-362.

${ }^{25}$ Memmingen: Albertus Kunne, 1482 (ISTC ir00268000; GW M38704; IBP 4793); Bern: Bernhard Richel, 1482 (ISTC ir00267000; GW M38680; IBP 4794); Kolonia: Ludvicus de Renchen, nie później niż 1483? (ISTC ir00269000; GW M38691; IBP 4795, HC 6914).
} 
Na podstawie dzieła Rolevincka powstały także trawestacje w językach walijskim i średnioangielskim. Popularność tej kroniki przygasa dopiero w latach trzydziestych XVI w. Jeżeli więc ostrożnie policzymy, że nakład każdego z wspomnianych wydań liczył tylko dwieście-trzysta egzemplarzy mamy do czynienia z rzędem wielkości 10000 egzemplarzy, które się rozeszły w niespełna trzydzieści lat! Przy okazji warto zauważyć, że sporo z nich trafiło na ziemie polskie - Incunabula Poloniae odnotowuja przeszło sto egzemplarzy (w tym zniszczone podczas drugiej wojny światowej) oryginału łacińskiego oraz kolejne kilkadziesiąt kopii przekładu niemieckiego.

Wydaje się, że na niecodzienny sukces czytelniczy Fasciculus temporum złożyło się kilka czynników. Pierwotne intencje Rolevincka nie odbiegały od encyklopedycznych pobudek jego poprzedników. Wyłożył je we wstępie do swego dzieła, stwierdzając, że pisze na użytek duchownych, a zwłaszcza tych, którzy kierują Kościołem, po to, by zapoznawali się z dorobkiem Ojców w zakresie studiów historycznych, ale także, by ułatwić im poruszanie się wśród nieraz przeczących sobie nawzajem informacji chronologicznych ${ }^{26}$. Tymczasem przyjęty przez autora graficzny schemat rozplanowania treści na rozkładówce książki, daleko posunięta skrótowość wykładu, posługiwanie się krótkimi całostkami tematycznymi (poszczególne osoby lub wydarzenia) zamiast potoczystej narracji, i chętne sięganie po materiał ilustracyjny (drzeworyty), wszystko to spowodowało, że w ręce czytelnika oddany został podręcznik historii powszechnej, który w nie tylko w systematyczny lecz także i obrazowy sposób wyjaśniał mechanizm dziejów, a jednocześnie ułatwiał ich zapamiętanie, stosując się do zasad ars memorativa ${ }^{27}$. Połączenie pomysłów autorskich Rolevincka z nową jakością na rynku księgarskim, jaką był druk, przyniósł efekt, który zapewne przerósł jego najśmielsze oczekiwania. Fasciculus temporum trafił nie tylko do osób, do których był skierowany, lecz także do szerokich rzesz czytelników, którzy pod wpły-

${ }^{26}$ Fasciculus temporum, k. 1r: „Cum non sine multa diligentia sanctorum patrum studia temporum decursus supputarunt non dubium quin magna vtilitas eccesiaticis viris et precipue illis qui ecclesiasticam politiam gubernare habent proveniat". Cytat ten oraz wszystkie kolejne odwołania do Fasciculus temporum zaczerpnięte są z wydania Hoernena (1474), dostępnego w Internecie (http://tudigit.ulb.tu-darmstadt.de/show/inciv-104).

${ }^{27}$ Na temat ars memorativa, zob.: The Medieval Craft of Memory: An Anthology of Texts and Pictures, ed. by Mary Carruthers and Jan M. Ziolkowski, Philadelphia 2002; Janet Coleman, Ancient and Medieval Memories: Studies $i$ the Reconstruction of the Past, Cambridge 1992; Mary J. Carruthers, The Book of Memory: A Study of Memory in the Medieval Culture, Cambridge 1990; Frances A. Yates, Sztuka pamięci, przeł. Witold Radwański, Warszawa 1977. 
wem devotio moderna sięgali po lektury pobożne celem doskonalenia się w wierze. Jego graficzne rozplanowanie kontinuum dziejów to już nie jest tablica synchronistyczna, który to pomysł powielali wielokrotnie kronikarze uniwersalni, przed Rolevinckiem i po nim, lecz swoista wizualizacja dziejów. Wizualizacja, która pozwalała kontemplować boski plan zbawienia ludzkości jako całość lub skupić się na jego poszczególnych elementach ${ }^{28}$. Można przypuszczać - brak jak dotąd badań temu poświęconych - że trafił również do rąk nauczycieli, którzy edukowali młodzież w szkołach parafialnych.

Fasciculus temporum był więc na przełomie wieków średnich i czasów nowożytnych tym dziełem, które musiało odcisnąć swe piętno na popularnym postrzeganiu dziejów jako takich oraz poszczególnych ich okresów. Ponieważ starożytność zaprzątała wówczas najbardziej twórcze i dociekliwe umysły, musiało to znajdować odbicie również w zainteresowaniach szerszych rzesz, a zwłaszcza w miastach, gdzie umiejętność czytania od dawna cechowała już nie tylko elity. Postrzeganie antyku wśród tych kręgów kształtował Werner Rolevinck. Zobaczmy więc, czego dowiadywał się przeciętny czytelnik u schyłku XV w. i na początku wieku XVI na temat starożytności z lektury najbardziej rozpowszechnionego podręcznika historii.

Zanim przejdziemy do szczegółowej charakterystyki dziejów starożytnych na kartach Fasciculus temporum, dla klarowności wywodu należy opisać przyjęty przez autora schemat wykładu. Większość kronik uniwersalnych, stosujących wizualny układ rozplanowania treści na stronie, posługiwała się różnymi odmianami tablicy synchronistycznej, w której następstwo lat, tak jak w roczniku, odnotowywano w pionie, a współczesne wydarzenia i postacie umieszczano w równoległych kolumnach w poziomie. Rolevinck, zapewne pod wpływem popularnych w późnym średniowieczu (a zwłaszcza w Anglii) kronik spisywanych w postaci

${ }^{28}$ Wpływ teologicznych koncepcji Jeana Gersona i szerzonych przez Braci Wspólnego Życia idei devotio moderna przeanalizowała L. C. Ward (Authors and Authority: The Influence of Jean Gerson, and the „Devotio Moderna” on the «Fasciculus Temporum» of Werner Rolevinck, „Analecta Carthusiana”, 62: Die Kartäuser und Ihre Welt - Kontakte und Gegenseitige Einflüsse, ed. James Hogg, t. 1, s. 171-188). W szerszym kontekście stosunku do wiedzy w środowisku kartuskim (i nie tylko) u schyłku średniowiecza omawia charakter kroniki Rolevincka Meta Niederkorn-Bruck, Werner Rolevinck: Wissensspeicher, Wissenswelt und Wissen von der Welt. Aufbereitung des Wissens bei den Kartäusern, [w:] Liber amicorum James Hogg. Kartäuserforschung 1970-2006, Meta Niederkorn-Bruck (ed.), dl. 6, Salzburg 2008 (Analecta Cartusiana, 210:6), s. 47-67. Por. także J. Soszyński, Od synchronizacji do wizualizacji. Prezentacja dziejów na kartach średniowiecznych kronik uniwersalnych, ,Z badań nad książką i księgozbiorami historycznymi”, 5:2011, s. 169-184. 
zwoju i przytwierdzanych niekiedy do ściany w reprezentacyjnych komnatach $^{29}$, zastosował następstwo lat rosnące wzdłuż poziomej osi ulokowanej pośrodku każdej pary kart, składających się na rozkładówkę książki. Przez środek więc każdej karty biegł poziomy pas, który sam rozpadał się na trzy paski: wąski górny pasek, w którym odnotowywane były lata rosnąco od 1 do 6673, czyli od stworzenia świata do roku 1474 według nowożytnej rachuby czasu. Poniżej znajdował się szerszy pasek, na którym $w$ odpowiednich chronologicznie miejscach powstawiane były koła, wewnątrz których widniały imiona osób, zakwalifikowanych przez autora do sukcesji nazwanej przez niego ,linea Christi”. Jeszcze niżej znajdował się drugi pasek chronologiczny, liczący lata od 5199 do 1, a następnie od 1 do 1474 - ,anni ante Christi nativitatem” i ,anni Domini”. Mamy tu więc jedno z pierwszych lub nawet pierwsze zastosowanie $\mathrm{w}$ kronice uniwersalnej rachuby lat przed naszą erą. Powyżej i poniżej owych trzech pasków systematyzujących upływ czasu (dla wygody nazwijmy je razem pasem chronologicznym) Rolevinck wstawiał, w postaci swoistych kapsułek tekstowych, zwięzłe informacje na temat postaci historycznych, wydarzeń oraz odnoszące się do nich komentarze i interpretacje.

Omówienie wizerunku starożytności w Fasciculus temporum zacznijmy od przyjętego przez autora podziału historii na okresy. Rolevinck w tym zakresie wyróżnia sześć ,etates mundi”: pierwsza, od Adama i Ewy do potopu, trwała 2242 lata; druga, od Noego do Abrahama, trwała 942 lata; trzecia, od Abrahama do Dawida, trwała 940 lat; czwarta, od Dawida do niewoli babilońskiej, trwała 485 lat; piąta, od niewoli babilońskiej do narodzin Chrystusa, trwała 590 lat; szósta, od narodzin Chrystusa do Sądu Ostatecznego. Przyjęty podział historii Rolevinck uzasadnia w krótkim komentarzu na samym początku kroniki, w którym wyjaśnia, że wieki świata wyróżnione zostały na podstawie podobieństwa $\mathrm{z}$ okresami życia pojedynczego człowieka ${ }^{30}$. Zauważa, że różni autorzy różnie wyznaczają ich początek i koniec oraz różnią się w obliczeniach ich długości, lecz odmawia relacjonowania tych sporów. Interesujące jest, że Rolevinck nie powołuje się tutaj na św. Augustyna, z myśli którego zaczerpnięty jest przyjęty przez niego schemat podziału dziejów ${ }^{31}$, choć w innych wypadkach na autorytet biskupa Hippony powołuje się bardzo chętnie. Interesująca nas historia starożytna (do upadku cesarstwa

${ }^{29}$ L. C. Ward, A Carthusian View of the Holy Roman Empire..., s. 29.

${ }^{30}$ Fasciculus temporum, k. 11v: „Mundi etates ... senectus siue hora nouissima.”

${ }^{31}$ De civ. XVI, 43. Na temat schematu sześciu wieków ludzkości, jego genezy i kontekstu filozoficznego, zob. J. A. Burrow, The Ages of Man: A Study in Medieval Writing and Thaught, Oxford 1988, s. 5-94. 
rzymskiego na zachodzie), obejmuje więc pierwsze pięć wieków świata i poważnie wkracza w szósty.

Właściwa narracja dziejów rozpoczyna się od sześciu dni stworzenia. Reprezentują je koła z napisami „Dies primus”, „Dies secundus” itd. uszeregowane $\mathrm{w}$ pionie, od lewego górnego rogu strony w dół, tak że dzień szósty wypada pośrodku karty i rozpoczyna pas chronologiczny (k. 2v). Na prawo od niego znajduje się kwadrat sygnalizujący początek pierwszej ery świata wraz ze stworzeniem Adama i Ewy. Prarodzice rozpoczynają jednocześnie ciagg postaci, określonych przez Rolevincka jako linea Christi. Uwzględnia ona synów Adama i Ewy i ich wybranych potomków ${ }^{32}$, a od Abrahama postępuje zgodnie z rodowodem Jezusa Chrystusa z pierwszego rozdziału Ewangelii wg św. Mateusza. Imiona tych postaci umieszczone są w kołach i uporządkowane według następstwa w czasie. Linea Christi ciagnie się do samego końca kroniki, z tym że po Jezusie wymieniony jest św. Piotr, a następnie kolejni papieże. W efekcie pas środkowy jest powiązaniem trzech aspektów: chronologii (uzgadnianej według anno mundi oraz anno ante Christi nativitatem), czynnika osobowego (linea Christi) i ciagłości. Pas środkowy symbolizuje jedność chrześcijaństwa. Użyte w schemacie koła mają również swoją wymowę symboliczna, wskazują na nieskończoność, czyli obietnicę życia wiecznego ${ }^{33}$.

Powyżej pasa chronologicznego znajdujemy komentarze wyjaśniające stworzenie świata w kategoriach teologicznych oraz wykład sześciu wieków świata, poniżej zaś omówione jest stworzenie człowieka i konsekwencje grzechu pierworodnego oraz zabójstwa Abla przez Kaina, w postaci państwa ziemskiego i państwa bożego według św. Augustyna. Omówieni są też ważniejsi potomkowie Seta.

Druga epoka (k. 3v-5r) przynosi już obfitszy zestaw informacji i wychodzi poza krag Biblii i jej amplifikacji. Większość wydarzeń i osób nadal jest przejęta $\mathrm{z}$ Księgi Rodzaju: wyłożona jest historia potopu i oszczędzenia Noego wraz z jego rodzina, niegodziwe zachowanie Chama wobec ojca i konsekwencje tego czynu, wreszcie podany jest szereg informacji wyjaśniających od których postaci starotestamentowych wywodzą się które ludy współczesne i historyczne. I tak na przykład dowiadujemy się,

${ }^{32}$ Sa to: Set, Enosz, Kenan, Mahalaleel, Jared, Henoch, Matuzalem, Lamech, Noe, Sem, Arfaksad, Sala, Eber, Falek, Heu vel Magau (Ragau), Seruch, Nachor i Tareg - por. Łk 3,34-38.

${ }^{33}$ Por.: Lotte Hellinga, Margaret Lane Ford, Deletion or Addition: A Controversial Variant in Werner Rolewinck's ,Fasciculus Temproum” (Cologne, 1474), „The Library Chronicle of the University of Texas", 21:1991, 3/4, s. 61-79; L. C. Ward, A Carthusian View of the Holy Roman Empire..., s. 30-31. 
że potomkowie Jafeta dali początek ludom europejskim: Gomer był praojcem Gallów, Jawan - Jonów czyli Greków, a Iberowie, czyli Hiszpanie, pochodzą od Tubala itd. Budowa wieży Babel i pomieszanie języków datowane jest około 2683 roku ab orbe condito, czyli około 2556 roku ante Christum natum. Biblijny Nimrod, sławny myśliwy i inicjator budowy wieży Babel, jest też łącznikiem z historią pozabiblijną. Po pomieszaniu języków miał się udać do Persów, których nauczył czcić ogień i których został królem; był też założycielem pierwszej dynastii władającej na Wschodzie, albowiem władze po nim przejął jego syn Belus. Rolevinck zaznajamia nas dalej z Belusem, jego syn Ninusem, legendarnym założycielem Niniwy, i jego żoną Semiramida. Wszyscy oni znani już są $\mathrm{z}$ historiografii greckiej. Władcy ci składają się też na pierwszy ciąg dynastyczny, zobrazowany powyżej pasa chronologicznego, w postaci połączonych poziomą linią kół, z wpisanymi imionami władców i kolejnymi numerami porządkowymi.

Przestrzeń poniżej pasa chronologicznego przynosi oprócz szczegółów genealogicznych postaci biblijnych także komentarze na temat genezy rozwarstwienia społecznego (wyodrębnienie się klasy nobilitas) oraz genezy bałwochwalstwa.

Trzeci wiek świata trwał od Abrahama do Dawida (k. 5v-9r). Obfitość materiałów, które Rolevinck przyporządkował do tej epoki jest już znaczna. Nieodmiennie dominują nadal postacie biblijne, chociaż coraz częściej odnotowujemy zapożyczenia z historiografii antycznej, np. Agialeus, legendarny założyciel królestwa Sykionu lub wspomniany już wcześniej twórca potęgi asyryjskiej Ninus. Zapożyczenia te najczęściej autor zawdzięcza lekturze św. Augustyna, czego bynajmniej nie ukrywa, kilkakrotnie powołując się na De civitate Dei, wraz z podaniem księgi. Oprócz kontynuowanej z poprzedniej epoki asyryjskiej linii dynastycznej pojawiają się linie władców greckich oraz faraonów egipskich. Około połowy XI wieku p.n.e. spotykamy informację o zdobyciu Troi przez Greków oraz o panowaniu Eneasza w Italii. Eneasz nie jest jednak pierwszym królem w Italii, lecz kolejnym ogniwem w linii zapoczątkowanej przez Janusa, o którym „mówia, że był synem Noego”. Informację identycznej treści znajdziemy u Marcina Polaka ${ }^{34}$.

Doły kolejnych kart, czyli przestrzeń rozkładówek poniżej pasa chronologicznego, dominują ważniejsze postacie starotestamentowe i wydarzenia z nimi związane. Szczególną rolę kronikarz, co zresztą jest jego cechą charakterystyczną także w tych momentach, kiedy omawia posta-

${ }^{34}$ Marcin Polak, Kronika papieży i cesarzy, s. 214. 
cie z historii pozabiblijnej, jest waga, którą przywiązuje do relacji pokrewieństwa.

O ile wiek czwarty, od Dawida do niewoli babilońskiej, zajmuje niewiele większą objętość niż trzeci (k. 9r-15v), to wiek piąty, doprowadzajacy wykład do narodzin Chrystusa, jest zdecydowanie obszerniej potraktowany (k. 15v-24r). Tematyka biblijna nadal jest obecna w obfitości, ale historia grecko-rzymska stopniowo zaczyna zapełniać coraz więcej miejsca, tak że pod koniec piątej ery zaczyna dominować.

Narodziny i życie Chrystusa oraz wydarzenia rozpoczynające szósty wiek świata (k. 24v-26r) naturalnie potraktowane są ze szczególną uwaga. Na rozkładówce 25v-26r zawieszony zostaje nawet schemat układu treści - przerwany jest pas chronologiczny, omówione jest natomiast znaczenie przełomu w dziejach, jaki stanowiło nadejście Syna Bożego. Na karcie 26v Rolevinck wraca jednak do przyjętego wcześniej układu treści, powyżej pasa chronologicznego ciagną się w przeważającej mierze dzieje świeckie, a poniżej koncentruje się na wydarzeniach związanych z życiem Kościoła; nie jest jednak bezwzględnie konsekwentny w tym podziale. Każdemu kolejnemu papieżowi, w mniejszym stopniu cesarzom, przyporządkowane są krótkie notki biograficzne, wyliczające ich najważniejsze dokonania. W tej części daje się zauważyć poważna zależność Wernera Rolevincka od Kroniki papieży i cesarzy Marcina Polaka. Wyliczani są święci i męczennicy, od czasu do czasu wspominani są ludzie pióra i nauki.

Więcej uwagi poświęcił autor postaci Konstantyna Wielkiego i jego zasługom dla Kościoła. Podkreślona została pobożność i waleczność cesarza, jak i jego zasługi w zakresie administrowania imperium. Podobnie pochwalnymi słowy potraktowany został papież Sylwester I, jakkolwiek nigdzie nie pada nawet aluzja do legendy o cudownym nawróceniu cesarza. Donacja Konstantyna, słynne fałszerstwo wczesnośredniowieczne, które przez długie stulecia służyło papiestwu za fundament roszczeń imperialnych, nie zostało przez Rolevincka przywołane z imienia, chociaż w komentarzu traktującym o prawie Kościoła do własności i o wyższości władzy duchowej nad świecka, spotykamy utrzymaną w aprobującym tonie aluzję do tego dokumentu ${ }^{35}$.

Trudno by doszukiwać się na kartach Fasciculus temporum cezury między antykiem a średniowieczem. Narracja dziejów imperialnych przeniesiona jest $\mathrm{z}$ cesarzy zachodnich na wschodnich, i tak trwa aż do

${ }^{35}$ Fasciculus temporum, k. 34v: „An non pocius usque hodie contradictores eorum formidabili vidimus morte consummatos iuxta quod imprecatus fuit eis Constantinus quando paginam imperialis testamenti propriis manibus super venerandum corpus beati Petri posuit" (podkreślenie moje, J.S.). 
Karola Wielkiego. Głównym wątkiem historycznym dla Rolevincka pozostaje sukcesja papieży.

Wizerunek starożytności przekazywany przez Fasciculus temporum jest zaskakująco konserwatywny. Była to historia biblijna z naciskiem na indywidualne postacie i związki zachodzące między nimi dominuje czasy przed narodzeniem Chrystusa. W okresie późniejszym rolę tę spełniała historia Kościoła. Uwagę autora przyciagają także uszeregowani w dynastie władcy, zwłaszcza ci, którzy mocnymi akcentami zapisali się w dziejach. Odnotowywane są elementy historii literatury i nauki. Daje się też zauważyć chęć wpisania własnej historii lokalnej w dzieje powszechne, $i$ to te najdawniejsze. Już na samym początku trzeciej epoki, obok Semiramidy, znajdujemy informację o założeniu Trewiru, czemu towarzyszy barwny drzeworyt. Można by rzec, jest to typowo średniowieczna historia świata. Podobny zestaw dat, faktów, postaci i interpretacji znajdujemy w kronikach uniwersalnych od czasów Euzebiusza z Cezarei. A przecież dzieło to powstawało w czasach, kiedy włoski humanizm z powodzeniem wdzierał się na północ kontynentu, w czasach, kiedy modne już wcześniej studia nad językiem i literaturą antyczną wzmocniły bodźce związane z pojawianiem się w Europie Zachodniej kolejnych fal uciekinierów $\mathrm{z}$ upadającego Bizancjum i związana $\mathrm{z}$ tym druga fala recepcji przekładów $z$ greki. Prace humanistów, co prawda skoncentrowane w poważnej mierze nad językiem, przyczyniły się jednak również do nowego, innego postrzegania antyku. W dziedzinie historiografii także zachodziły istotne zmiany, śladów których próżno by szukać u Rolevincka. Wzrastała rola krytycznego myślenia, czego przykładem niech będzie zakwestionowanie przez Mikołaja z Kuzy, Lorenza Vallę, a następnie Reginalda Peacocka autentyczności Donacji Konstantyna. Okazuje się jednak, że elitarne studia humanistów bardzo powoli przenikały do szerszych kręgów czytelniczych. Jedyne, można powiedzieć, co różni Fasciculus temporum od dawniejszych kronik, to pominięcie bajkowych treści rodem z legend świętych i egzemplów, ale i to można wytłumaczyć nie tyle rozwiniętym zmysłem krytycznym, co brakiem miejsca wynikającym z ograniczonej ilości pola do zapełnienia na karcie formatu folio.

Fasciculus temporum powstał w innym środowisku i skierowany był do innego odbiorcy; w efekcie też spełniał u swoich czytelników inną funkcję. Jego autorem był mnich, kartuz, który pojmował pisarstwo historyczne nie jako działalność naukową lecz jako służbę bożą. Zapis dziejów w jego rozumieniu to uprzystępnienie boskiego planu zbawienia zwykłym ludziom, dostarczenie im materiału faktograficznego, głównie rodem z Biblii, i uproszczonej interpretacji teologicznej. A przedstawiona 
wizualizacja, oprócz oczywistego przekazu dydaktycznego, łatwo w rękach pobożnego czytelnika mogła się przerodzić w podstawę medytacji nad dostojeństwem i wspaniałością dzieła Boga ${ }^{36}$.

$\mathrm{Z}$ ideałami devotio moderna, bardzo żywymi w piętnastowiecznych środowiskach kartuskich, kronikę Wernera Rolevincka łączy także świadome sięgnięcie po medium druku ${ }^{37}$. Książka drukowana odgrywała ważną rolę wśród wyznawców nowej pobożności. Wystarczy tutaj wspomnieć, że ruch Braci Wspólnego Życia - zainspirowany przez Gerharda Groote, twórcę devotio moderna - położył wielkie zasługi nie tylko $\mathrm{w}$ upowszechnianiu $\mathrm{w}$ środowiskach mieszczańskich słowa pisanego jako takiego lecz także drukowanego, m.in. przez zakładanie warsztatów drukarskich.

\section{Streszczenie}

\section{Dzieje starożytne w Fasciculus temporum Wernera Rolevincka}

Powstały w latach 1468-1472 Fasciculus temporum kartuza Wernera Rolevincka należy do ostatniej fali średniowiecznych kronik uniwersalnych, które swe upowszechnienie zawdzięczają już nowemu medium druku. Niemniej treści przekazywane przez tę kronikę w odniesieniu do historii starożytnej, zaskakują swym konserwatyzmem. W porównaniu z takimi kronikami jak Marcina Polaka (XIII w.) lub nawet wcześniejszymi, Rolevinck ani na jotę nie wydaje się nowocześniejszy ani pod względem relacjonowanych wydarzeń ani ich interpretacji. Tymczasem współczesna mu historiografia renesansowa traktowała starożytność już w inny sposób. Niemniej to właśnie Fasciculus temporum zażywał niezwykłej popularności, rozpowszechniony w czternastu wydaniach w pierwszym dziesięcioleciu po ukazaniu się editio princeps, i w co najmniej kolejnych czternastu do śmierci autora w 1502 r., by nie wspomnieć o przekładach na języki narodowe.

Zjawisko popularności dzieła Rolevincka daje się wytłumaczyć tylko poprzez skierowanie wzroku ku zupełnie innemu odbiorcy niż publiczność wysoko wykształcona, czyli typowy czytelnik średniowiecznych kronik uniwersalnych. Fasciculus temporum należy postrzegać jako element ruchu religijnego zwanego devotio moderna. Kronika ta powstała z myślą nie tyle o intelektualistach co zwykłych ludziach, którzy mieli przy jej pomocy poznawać naukę o boskim planie zbawienia wpisanym w dzieje ludzkości. Odnotowywała podstawowe

\footnotetext{
${ }^{36}$ Por. wyżej przyp. 28.

${ }^{37}$ Por. wyżej cytat dyskutowany w przypisie 14.
} 
wydarzenia i postaci historii biblijnej i późniejszej, porządkując je chronologicznie. Przedstawiała także oryginalną wizualizację dziejów, osiągniętą w drodze specyficznego rozplanowania graficznego tekstu, podkreślającego ciagłość historii. Wizualizacja ta mogła więc być wykorzystywana nie tylko do celów dydaktycznych lecz także do medytacji. Co więcej, wszystko wskazuje na to, że sięgnięcie przez Rolevincka po druk nie było dziełem przypadku lecz całkowicie świadomym zabiegiem, mającym na celu jak najszersze upowszechnienie książki. Cecha ta również łączy kartuskiego autora z devotio moderna.

\section{Summary}

\section{Ancient History in Werner Rolevinck's Fasciculus Temporum}

Composed between the years $1468-1472$ by the Carthusian monk from Cologne Werner Rolevinck, the Fasciculus Temporum belonged to the last wave of medieval universal chronicles, distinguished by the fact that these works received immediate printed distribution. However, the information content and type furnished by Rolevinck with respect to ancient history is truly disillusioning. Compared to previous authors of universal chronicles, ranging back to Martinus Polonus $\left(13^{\text {th }} \mathrm{c}\right.$.), or even earlier writers, Rolevinck's data and interpretations differ in no respect at all. When one remembers that contemporary renaissance historians were already depicting antiquity in a very different manner, Rolevinck's attitude seems truly out of place. And yet his work enjoyed tremendous popularity even measured by the standards of the printed book. Over the ten years from the first edition, his chronicle was reprinted fourteen times, and at least that many times over the following years, until his death in 1502 .

The phenomenon of Rolevinck's popularity cannot be explained otherwise than by pointing to a completely different function of the book than learned use, typical for earlier universal chronicles. The Fasciculus Temporum should be treated as an element of the religious movement known as devotio moderna. The chronicle was not intended for the intellectuals, but for ordinary people, who could learn from it the doctrine of the divine plan for human salvation inscribed into the history of mankind. The book offered not only the basic facts and names of Biblical history, but also an original visualisation of the historical process in its graphical layout, which could be meditated on. Moreover, it seems that the use of print on the part of Rolevinck was conscious and intentional. This feature too links him with the devotio moderna. 